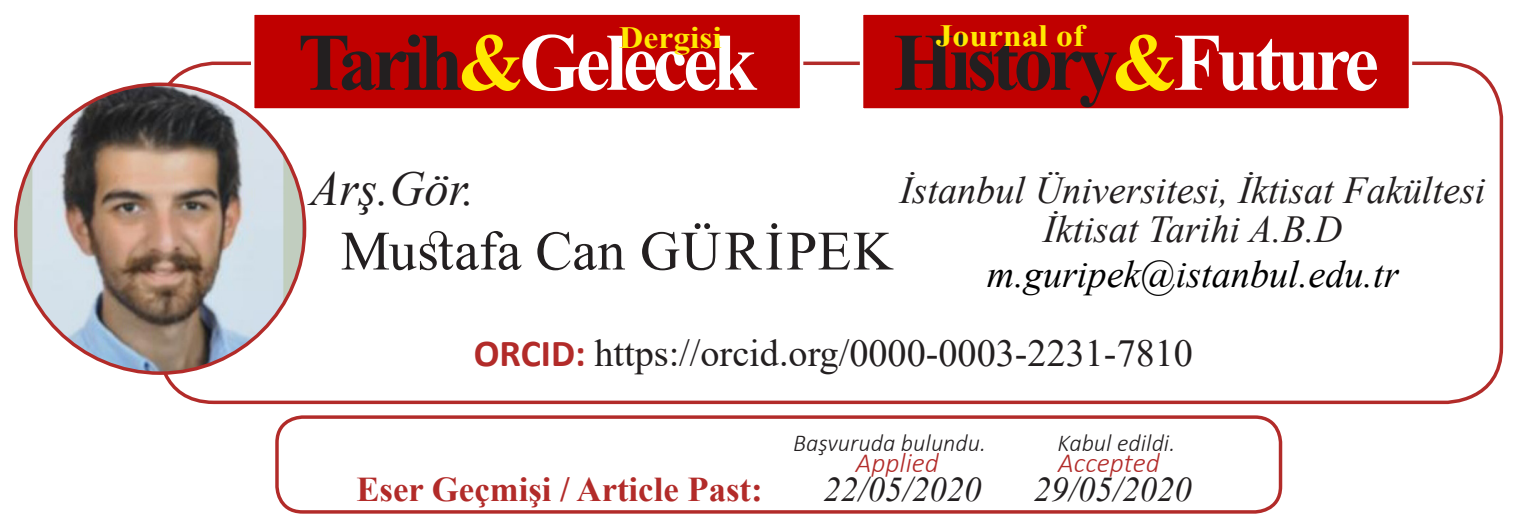

Araştırma Makalesi

DOI: http://dx.doi.org/10.21551/jhf.741224

Research Paper

Orjinal Makale / Orginal Paper

\title{
XV. ve XVI. Yüzyıl Osmanlı, Avrupa ve Çin Loncalarına Dair Karşılaştırmalı Bir Bakış
}

\author{
A Comparative Overview of the Ottoman, Europe and Chinese \\ Guilds in XV-XVI. Centuries
}

\section{Öz}

Bu makalede XV. ve XVI. Yüzylllarda Osmanlı Imparatorluğu'nda, Avrupa'da ve Çin'de lonca tipi esnaf örgütlenmeleri karşılaşstırmalı bir bakış açısılyla ele alınmıştır. Lonca kurumu, birbirinden farkl coğrafi, siyasi, ekonomik, dini-kültürel özellikleri olan bu üç bölge için de ortak bir yapıdır. Tarihi süreç içerisinde loncaların bu üç coğrafi bölgede ortaya çıkmalarının altında yatan nedenlerden başlayarak, hangi ihtiyaçlara cevap verdiği, ne gibi misyonlarının olduğu, örgütlenme şemaları gibi temalar baz alınarak karşılaştırma yapılmıştır. Aynı zamanda ekonomik, sosyal ve dini fonksiyonlar üstlenerek hem toplumsal hem de siyasi alanda önemli bir yer kaplayan loncaların günümüze kadar ulaşamamalarının nedenleri üzerinde de durulacaktır. Iktisadi hayat başta olmak üzere çok önemli roller üstlenen lonca kurumu, dikkat çekici bir şekilde üç coğrafyada da ilginç benzerlikler taşımaktadır. Ancak; Avrupa'da loncalar altın çă̆ı olarak adlandırabileceğimiz dönemini Osmanlı Imparatorluğu ve Çin'e göre daha erken yaşamış, Osmanlı ve Çin'deki loncalar daha sonraki zamanlarda etkili olabilmişlerdir. Osmanlı Imparatorluğu'nda loncaların etkisini kaybetmeye başladığ dönemde ise Çin'deki loncalar önem kazanmaya başlamıştır.

Anahtar Kelimeler; Loncalar, Orta Çă̆, Osmanlı Imparatorluğu, Çin, Avrupa

\section{Abstract}

In this article; guild type organizations in the Ottoman Empire, Europe and China will be handled with a comparative perspective in $X V$. and XVI. centuries The guild institution is a common structure in all three regions with different geographical, political, economic, religious and cultural characteristics. Starting from the reasons underlying the 
emergence of the guilds in these three geographical regions in the historical process, they were compared on the basis of themes such as what needs they met, what missions they had, organizational charts. The reasons why the guilds, which occupy an important place in both social and political areas by undertaking economic, social and religious functions, have not reached today. The guild institution, which plays very important roles, especially in economic life, has interesting similarities in all three geographies. But; In Europe, guilds lived earlier than the Ottoman Empire and China, which we can call the golden age, and the guilds in the Ottoman and China were effective later. In the period when the guilds started to lose their influence in the Ottoman Empire, guilds in China started to gain importance.

Key Words; Guilds, Crafts, Middle Age, Ottoman Empire, China, Europe

\section{Avrupa ve Asya'da Lonca Tipi Esnaf Örgütlenmelerinin Ortaya Çıkışı}

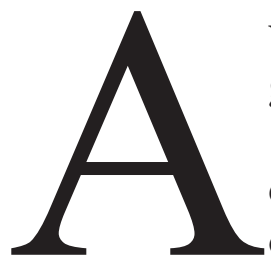

vrupa'da lonca tipi örgütlenmelerin ortaya çıkışı ile ilgili çeşitli görüssler ve tezler ileri sürülmüştür. Umberto Eco bu tezleri; - Roma "collegialarının" devamı nitelikte olan Ortaçağ zanaatkâr ve esnaf dayanışmaları, - Kuzeydeki germen istilasından sonra Roma tipi örgütlenmelerin bağları kopsa da tekrardan kurulan bağlarla birlikte oluşturulan loncalar, - yine Roma döneminden kalan bir anlayışla esnaf ve zanaatkârlar arasında resmi olmayan bir yeminle oluşturulan prototipin örnek alınarak yapılanan örgütler ve iktidar ilişkileri çerçevesinde örgütlenen yapılar olmak üzere dört ana başlıkta toplar. ${ }^{1}$ Eco, kentlerin gelişimiyle birlikte iktisadi hayatın canlanmasının kaçınılmaz bir gelişme olduğunu ve zanaatkârların şehir hayatındaki etkisinin arttığı için bu tür bir örgütlenme yoluna gidebileceklerini söyleyerek de kendi tezini ortaya koymuştur. ${ }^{2}$

Eco'nun aktardığı tezlerin ortak noktası olan Roma dönemi esnaf ve zanaatkârlarına bakıldığında; "collegiaların" temelinin "vicinae" veya "vicinantiae" adı verilen bir anlayışa dayandığı görünmektedir. Bu anlayış; "iyilik komşudan, kötülük yabancıdan gelir' şeklinde ifade edilebilir. Dayanışma ve bilinmeyenden gelen zorluklara karşı beraber direnç oluşturma güdüsü ufak çaplı komünler içerisinde hâkim olmuş ve 10-12.yüzyıllarda loncaların ilk nüvesini oluşturmuştur. ${ }^{3}$

Ortaçağ iktisat tarihiyle ilgili önemli çalışmalara imza atan Henri Pirenne; loncaların tarihsel kökenlerinin nereye dayandığından ziyade, tarihin akışı içerisinde oluşacak iki temel dinamiğin harekete geçmesinin loncaları oluşturduğu tezini ortaya sürer. Bu dinamikleri de "yasal otorite" ve "gönüllü birlik" olarak belirler. Yasal otoritenin oluştuğu andan itibaren kamu yararını gözetecek olması piyasada tüketiciyi korumaya yönelik politikaları da beraberinde getirecektir. Belirli bir metanın ticaretini, üretimini yaparak kâr etmek

1 Umberto Eco, Ortaçağ, Barbarlar-Hristiyanlar-Müslümanlar, çev. Leyla Tonguç Basmacl, 2. bs (İstanbul: Alfa Yayınları, 2014), 280.

2 Umberto Eco, 280.

3 Jacques Le Goff, Ortaçağ Batı Uygarlığı, çev. Hanife Güven, Uğur Güven, 280280 (Ankara: DoğuBatı Yayınları, 2015), 321. 
isteyen insanlar da bir araya gelerek kendi çıkarlarını daha iyi koruyabilmek için harekete geçecektir. Böylece yasal otoritenin altında çalışan gönüllü birlikler olarak loncaların ortaya çıktığı tezini ileri sürer. Pirenne, bunlara ek olarak Ortaçağ Avrupası'nda yasal otoritenin kilise gibi bir dini kurum olduğundan dolayı, loncaların Katolik ahlakına göre dizayn edildiklerini ileri sürer. ${ }^{4}$

Avrupa'daki loncaların kökenleri Roma döneminden kalan bir miras ya da Ortaçağ'da ortaya çıkan bir yapı olarak kabul edilsin, küçük esnaf ve zanaatkârların dişarıdaki bilinmeyenlere karşı bir dayanışma güdüsüyle toplu şekilde hareket etmelerini sağlayan yapılardır. Buna benzer bir şekilde Osmanlı İmparatorluğu'ndaki loncaların kökenlerine yapılan referanslar da pek farklı değildir.

XIII. ve XIV. Yüzyıllarda Moğol istilalarının siyasi ve iktisadi yapıyı temelinden sarsması Anadolu'da bir otorite boşluğu meydana getirmişti. Bu siyasi ve ekonomik buhranda bir araya gelerek kentlerdeki otorite boşluğunu doldurmaya çalışanlar yerel esnaf ve zanaatkârlar olmuştur. Bu kişiler genel olarak "ahiler'” adıyla anılmaktadır. Şehirlerin yönetiminde dayanışmayı ve iş birliğini temel alarak birleşen gruplar ekonomik olarak da iş birliği yaparak piyasada etkin bir rol oynuyordu. Bazı önemli tarihçiler bu ekonomik ve siyasi kaynaşmanın dini ve ahlaki motiflerle bezendiği ahiliğin ortaya koyduğu kural ve kaidelerin loncalara miras kaldığını savunur. ${ }^{5}$ Ahilerin kendi iç düzenlerinde ortaya koydukları kuralların (düsturlar); fütüvvet anlayışına dayandığını ve köklerinin İslami anlayışına uygun olduğunu vurgulayan Halil İnalcık da loncaların ahilik anlayışına dayanarak oluşan yapılar olduğunu belirtmiştir. ${ }^{6} \mathrm{Bu}$ anlayış gereği ahilerin ve devamı niteliğinde olan loncaların fütüvvetname adı verilen kurallar bütününe göre yönetildiği dile getirilmektedir.

Loncaların fütüvvet anlayışıyla hareket ederek, dini yönlerinin daha ağır bastığını ve ahilerle doğrudan ilişkili olduğunu ileri süren tezlere mesafeli yaklaşanlar da vardır. Loncaların, ahilerden sosyal ve ekonomik olarak bir örgütsel kültür mirası almış olabileceğini kabul etmekle birlikte günün şartlarına yönelik, daha esnek bir yapı olduğu tezi de ileri sürülmüştür. ${ }^{7}$ Osmanlı İmparatorluğu'ndaki loncaların izini süren Eunjeong Y1 ise; Loncaların söylenildiği gibi İslami köklere sahip olup olmadığını tartışmaya açarak, loncaların siyasi, iktisadi ve sosyal dayanışma duygusuyla hareket eden insanların bir araya gelerek oluşturdukları yapılar olduklarını, genel kanıların aksine birkaç lonca hariç dini misyonun ön plana çıkmadığını iddia eder. ${ }^{8}$ Osmanlı İmparatorluğu'nda ve Avrupa'da loncaların kökenleri ve kendinden önceki esnaf, zanaatkâr örgütleriyle devamlılığ meselesindeki çeşitli tezlerden sonra, Çin'deki tarih yazımında loncaların kökenleri

4 Henri Pirenne, Ortaçağ Avrupa'sının Ekonomik ve Sosyal Tarihi, çev. Uygar Kocabaşoğlu, 3. bs (İstanbul: İletişim Yayınları, 2011), 201.

5 Bernard Lewis, "The Islamic Guilds", The Economic History Review 8, sy 1 (1937): 20-37; Suraiya Faroqh, Osmanlı Kültürü ve Gündelik Yaşam, çev. Elif Kılıç, 5. bs (İstanbul: Tarih Vakfı Yurt Yayınları, 2005), 58-59.

6 Halil İnalcık, Osmanlı Imparatorluğu Klasik Çağ (1300-1600), çev. Ruşen Sezer, 18. bs (İstanbul: Yapı Kredi Yayınları, 2013), 157-58.

7 Gabriel Baer, Fellah and Townsmen in the Middle East: Studies in Social History (Londra: Frank Cass, 1982).

8 Eunyeong Yı, 17.Yüzyıl İstanbul'unda Lonca Dinamikleri, çev. Barış Zeren (İstanbul: Türkiye İş Bankası Kültür Yayınları, 2018). 
incelenirken görülecektir ki; tıpkı Osmanlı ve Avrupa'da olduğu gibi Çin'de de loncaların kökenleri tartışmalı bir konudur.

\section{1. Çin'de Lonca Tipi Esnaf Örgütlenmelerinin Ortaya Çıkması}

Çin'deki lonca tipi örgütlenmelerin kökenleri genellikle XI. yüzyılda kutsal tapınaklarda bir araya gelerek ticaret yapan tüccar gruplarına dayandırılmaktadır. "Hanghui"' veya "gongsua" adı verilen tüccar birlikleri; uzun mesafeli ticarette meydana gelebilecek riskleri azaltmak, depo yerlerinin kirasını birlikte karşılamak ve pazarlık gücü oluşturmak için birlikte hareket etmeye başlamışlardı. Tek başına hareket etmekte zorlanan satıcılar bu tip ufak, komünal gruplar içerisinde daha rahat hareket edebiliyorlard1. ${ }^{9}$ Tüccarların daha kârlı ticaret yaptıklarını gören ipek üreticileri hem üretim maliyetlerini düşürmek hem de satış pazarlarını genişletmek için örgütlenmeye başlamışlardı. XIII. Yüzyıl sonları ve XIV. Yüzyıl başlarında ortaya çıkan ipek üreticilerinin dayanışmalarının Çin'deki loncaların kökenini oluşturduğu tezini doğurmuştur. ${ }^{10}$

İlk Çin loncalarını inceleyen Peter Golas ise; kökenlerin XV. yüzyılda bölgeler arasında ticaret yapan tüccarlara dayandığını ileri sürmektedir. Bazı tüccarların bir bölgeden diğer bölgeye gittiğinde satış yerleri kurduğunu, küçük esnaf ve zanaatkârların da bu satış yerleri etrafında toplanarak ortak bir ticari ağ oluşturduğunu ileri süren Golas, devletin de bu ufak yapıları desteklemesi ve denetlemesiyle birlikte loncaların ortaya çıktığını belirtmektedir. ${ }^{11}$

Loncaların kökenleri tartışmalarında hem Avrupa hem Osmanlı hem de Çin bölgesinde iki tane ana akım tez ortaya atılmıştır. Bunlardan ilki bölgenin dini inancına göre loncaya bir köken bulunmasıdır. Avrupa'da Roma dönemi Hristiyanlığına ve ileride detaylı bir şekilde değineceğimiz Katolik ahlak anlayışına atıf yapılarak; ilk prototipler ve kurumsal loncalar arasında bir bağ kurulmaya çalışılır. Yine bu tez içerisinde Osmanlı loncaları, ahilik ve İslam potasında eritilerek dini kökenlerine dikkat çekilmeye çalışılır. Çin loncalarının aslında tapınaklardaki dindar tüccarlardan çıktığı tezi de yine bu tez içerisindedir. Yani loncaların kökenleri araştırılırken eski kurumların dini yönlerine atıf yapılması incelenen üç bölge için de benzer bir özelliktir.

Dini anlayışın loncaları şekillendirdiğini ve kökenini oluşturduğu tezinin yanı sıra, küçük esnaf ve zanaatkârların dayanışma güdüsüyle hareket ederek, işleyecekleri malların ham maddelerini daha ucuza satın almak ve işledikten sonra pazarda zarar etmeden satmaları için örgütlendikleri tezi öne sürülmüştür. Avrupa'daki "collegialar', Anadolu bölgesindeki “'ahiler”' ve Çin'deki 'gongsualar' bu amaçlar ve güdüler etrafinda bir araya gelen kişilerin oluşturdukları yapılardır. İncelemeye söz konusu olan üç bölge için de lonca sisteminin kökeniyle ilişkilendirilen bu tip yapıların varlığı da lonca oluşumlarının ana motivasyonunun zaman ve mekândan bağımsız olarak benzerlik taşıdığını ortaya koymaktadır.

9 Christine Moll-Murata, "Chinese Guilds from the Seventeenth to the Twentieth Centuries: An Overview", IRSH 53, sy 1 (2008): 218.

10 Christine Moll-Murata, 219.

11 Peter Golas, "Early Ch'ing Guilds", içinde The City in Late Imperial China (Stanford: Stanford Universtiy Press, 1977), 557. 


\section{Loncaların Ekonomik, Sosyal ve Dini Fonksiyonları}

\subsection{Ekonomik Düzenlemeler}

XV. ve XVI. yüzyıllarda lonca sisteminin Avrupa'daki, Osmanlı İmparatorluğu'ndaki ve Çin'deki yansımalarını incelerken, ilk olarak loncaların faaliyet alanlarına bakılması bu üç bölgedeki lonca sistemi dinamiklerinin anlaşılmasında fayda sağlayacaktır. Loncalar ekonomik, sosyal ve dini olmak üzere üç temel alanda faaliyet göstermektedir.

Avrupa'daki loncaların ekonomik hayata dair düzenlemelerinin başında aynı iş ve mesleği yapanların aynı iş kolunda örgütlenmesi gelmektedir. Aynı zanaatta faaliyet gösteren kişiler aynı lonca altında birleşirdi. Bu sebeple de her bir loncanın faaliyet sahası önceden belirlenmiş oluyordu. Örneğin; un ticareti yapan tüccarların loncası ayrı, onu ekmek haline getiren firıncıların loncası ayrıydı. ${ }^{12}$ Loncaların iş sahalarına bağlı olarak çeşitlilik göstermesi hem ekonomik düzenin korunmasına yardımcı oluyor hem de loncalara kesin sınırlar çizerek denetimlerini kolaylaştırıyordu. Ancak, XV. ve XVI. yüzyıllarda Avrupa'da loncaların ekonomideki esas rolleri ekonomik düzenin korunması hususundaydı.

Loncaların ekonomik hayata dair en önemli işlevi mal arzını ve buna bağlı olarak piyasa fiyatlarını denetlemekti. XIV. yüzyılda Avrupa'da Aquinas'lı Thomas ve takipçilerinin ısrarla üzerinde durduğu Katolik ahlak anlayışı, loncaların piyasadaki işlevini açık bir şekilde ortaya koymaktadır. Thomas ve takipçileri ' bir malın fiyatının, değerini aşmaması gerektiği” ' öğretisini dini metinler aracılığıyla açıklamaya çalışmış ve alışveriş sırasında ne alıcının ne de satıcının zarar etmemesi gerektiğini vurgulamışlardır. ${ }^{13} \mathrm{Bu}$ öğreti Kilise ve şehir yönetiminin ekonomik alanda "kazanç hırsını mahkûm”, ederek sermaye dağılımını denetleme isteğine meşruiyet sağlamaktadır. ${ }^{14}$ Kilise'nin bu öğretisi ekonomiye müdahale aracı olarak loncaların örgütlenmesini zorunlu kılmıştı. Kilisenin ekonomik düzen öğretisinin temelini “ "adalet", oluşturuyordu. Bir malın fiyatı belirlenirken onun değeri ve fiyatı birbirine eşit olmak zorundaydı ve buna 'adil fiyat" (just price) deniliyordu. Loncalar, bağlayıcı kurallar koyarak ve bu kuralların çiğnenmesi durumunda yargılama, para cezası verme ve diğer yöntemlerle cezalandırma yetkisini elinde bulundurarak piyasayı denetliyordu. ${ }^{15}$ Avrupa'da Kilise ve şehir yönetiminin adil fiyat uygulamasının denetlenmesinde loncaları yetkili kılması loncalara ekonomik hayatta geniş bir hareket sahası sağlamıştı. Bu sayede; piyasa fiyatından düşük bir fiyata ham madde alıyorlar ve kendi belirledikleri ' adil', piyasa fiyatından satarak tekel gücü oluşturuyorlard1. ${ }^{16} \mathrm{Bu}$ tekel gücü sayesinde hem lonca içindeki rekabet hem de loncalar arası rekabet minimum seviyeye indirilirken ekonomide loncalarla yarışa girebilecek grupların önü kesilmiş oluyordu. ${ }^{17}$ Osmanlı İmparatorluğu’nda

12 Georges Renard, Guilds in The Middle Ages, çev. Dorothy Terry (Ontario: Batoche Books, 2000), 20-32.

13 Raymond de Roover, "The Concept of the Just Price: Theory and Economic Policy", The Journal of Economic History 18, sy 4 (1958): 418-34.

14 Mehmet Ali Ağaoğulları, Sokratesen Jakobenlere Batı'da Siyasal Düşünce, 2. bs (İstanbul: İletişim Yayınları, 2011), 254-62.

15 Nathan Rosenberg ve L.E. Birdzell, Batı Nasıl Zengin Oldu, çev, Erdal Güven (İstanbul: Form Yayınları, 1992), 65-69.

16 John Baldwin, Masters, Princes, and Merchants, The Social Views of Peter The Chanter His Circle, c. 1, 2 c. (Princeton: Princeton University Press, 1970).

17 John Baldwin, "The Medieval Theories of Just Price; Romanists, Canonists, and Theologians in Twelfth and Thirteenth Centuries", Transactions of The America Philosophical Society 49, sy 4 (1959): 49. 
faaliyet gösteren loncalar, Avrupa'da olduğu gibi kendi meşgul oldukları iş koluna dayalı bir şekilde örgütleniyorlardı. Devlet, ekonomik hayatı düzenlemek için ihtiyaçtan fazla mal üretilmesini istemiyor, bunu üretecek olan esnafları loncalar sayesinde denetliyor ve sınırlı tutuyordu. Şehir ve taşra arasındaki sınırların kalkmadığı, uluslararası ticaretin çok etkin olmadığı bir dönemde devlet; açılacak dükkân (gedik) sayısını sınırlı tutarak ekonomiyi kontrol ediyordu. ${ }^{18}$ Ekonominin denetlenmesinde Osmanlıların kullandığı en önemli araç İhtisap Kanunları'ydı. İhtisap kanunları sayesinde piyasadaki malların fiyat1, kalitesi gibi temel şartlar belirleniyordu. Bunların belirlenmesinde ve denetiminde devlet otoritesi loncalarla işbirliği yapıyordu. ${ }^{19}$ Avrupa'daki "adil fiyat" uygulamasının bir benzeri Osmanlı İhtisap Kanunları'nda "narh" adıyla yer alıyordu. Mal ve hizmet fiyatlarında devletçe tespit edilen üst $\sin ^{20}{ }^{20}$ olarak açıklanan Narh uygulamasında; kar haddi $\% 5$ ile \%15 arasında değişirdi. Bu kar oranlarına uymayan ve daha fazla kar elde etmek isteyen kişilere ciddi cezai yaptırımlar uygulanırdı. ${ }^{21}$

Narh uygulaması sayesinde piyasadaki fiyat dalgalanmalarının ve fiyat artışlarının önüne geçilmeye çalışılır, piyasadaki ürünlerin reayaya ulaştırılmasında hassasiyet gösterilirdi. ${ }^{22}$ Kısacası Osmanlı İmparatorluğu'nda devlet koyduğu kurallarla, hem ekonomik hayatta tüketici pozisyonunda olan reayasını koruyor hem de üreticileri denetlemek için loncaları kullanıyordu. İhtisab kanunları çerçevesinde üreticiye kendi otoritesini kabul ettirirken, loncalara da ekonomik kazanç sağlayarak onları da güvence altına alıyordu. ${ }^{23}$ XV. ve XVI. yüzyıllarda Çin'de aynı iş kolunda ve meslekte faaliyet gösteren esnaf ve zanaatkârların ekonomik alanda üstlendikleri başlıca rolleri şu şekilde sıralanabilir; ${ }^{24}$

\section{Ücretlerin ve fiyatların düzenlenmesi}

- Piyasada ya da bir meslekte faaliyet göstermek isteyen kişilerin düzeninin sağlanmasi

- İş gücünün değerlendirilmesi

- Ham madde giriş-çıkışlarının denetlenerek ülkeden ham madde çıkmasının engellenmesi

Ekonomik hayatta lonca gibi bir kuruma neden ihtiyaç duyulduğu ve bu rollerin

18 Halil İnalcık, Devlet-i Aliyye, Osmanlı Imparatorluğu Üzerine Araştırmalar-I, 52. bs (i̇stanbul: Türkiye İ̧̧ Bankası Kültür Yayınları, 2013), 297-301.

19 Murat Özyüksel, Feodalite ve Osmanlı Toplumu, Derin Yayınları, istanbul (İstanbul: Derin Yayınları, 2007), 202.

20 Mübahat Kütükoğlu, "Narh”, içinde TDV islam Ansiklopedisi (Ankara: Türkiye Diyanet vakfı, 2006), 39091. Narh uygulaması modern mikro iktisadi politika olan tavan-taban fiyat politikasıyla/kontrolleriyle aynı minvaldedir.

21 Mehmet Genç, Osmanlı Imparatorluğunda Devlet ve Ekonomi, 9. bs (İstanbul: Ötüken Yayınları, 2013), 47.

22 Şevket Pamuk, Osmanlı-Türkiye iktisadi Tarihi 1500-1914, 9. bs (İstanbul: illetişim Yayınları, 2014), 63.

23 *Bu durum aynı zamanda ekonominin sıfır toplamlı olduğunu kabul etmekle beraber, rekabeti azaltacak kurumların oluşmasını, üretici birlikleri kurma fikrini ifade etmektedir.

Halil İnalıık, Osmanlı Imparatorluğu Klasik Çağ (1300-1600), 160-62.

24 Willim T. Rowe, Hankow: Commerce and Society in a Chinese City, 1796-1889 (Stanford: CA, 1984), 60. 
üstlenilmesi Çin'de VII. yüzyıldan beri tartışılan konulardı. VII. Yüzyılda Fu Xuan'ın felsefesi ekonominin her zaman sosyal yönlerinin öne çıkarılmasını öğütlüyordu. Ekonominin doğasında rekabet olmadığını, oluşturulacak mutualist birliklerle* rekabetin ve kazanç peşine düşme gibi "ahlaksızlıkların' önüne geçilebileceğini ileri sürüyordu. ${ }^{25}$ XV. ve XVII. Yüzyıllar arasında Çin'de önemli eserler veren ve hükümdarlara danışmanlık yapan Weng Fuzhi, Huag Zongxi ve Gu Yangwu gibi isimler, hükümdarın en önemli iktisadi görevlerinde üç maddede mutabık kalıyorlardı. Hükümdarın halkının refahını sağlayabilmesi ve onları mutlu edebilmesi için ; - fiyatları sabit tutması, - gelir dağılımındaki adaletsizlikleri ortadan kaldırması, - kaynaklardan ve firsatlardan herkesi adil yararlandırması gerektiği düşünülüyordu. ${ }^{26} \mathrm{XV}$. ve XVI. yüzylllarda iktisadi düşüncenin ve felsefenin belirlediği ihtiyaçlar Çin loncalarıyla karşılanmaya çalışıldı. Devletin ekonomiye bakış açısı; bölgeler arası ticaretin canlanması ve ülke içinde ihtiyaçların karşılanmasına dayanıyordu. Çin hükümdarları lonca gibi özerk (sayılacak kurumlara karşı ön yargılı olsa da bölgeler arası ticarette ve piyasada oynadıkları rolden dolayı yaptırım uygulamıyordu. ${ }^{27}$

Hükümdarların, taşra idaresinin denetimine bıraktığı loncalar; ekonomik mutualizm temelinde örgütlenmişti. Loncadaki her birey birbirine muhtaç olduğu gibi, bölgedeki her lonca da bir diğer loncaya muhtaçtı. Herkesin birbirine muhtaç olduğu bir ekonomik planda rekabet de önlenmiş oluyordu. Rekabetin önlenmesi; kimsenin bir diğerinin satışını azaltmaması için gerekliydi. Malın bolluğu ve darlığı sürekli takip edilerek uzun dönemli fiyat ayarlaması yapılıyordu. Sabit fiyat uygulayarak hem karaborsacılar hem de aşırı kar elde etmek isteyen satıcılar engelleniyordu. ${ }^{28}$ Çin'in kuzeyi ve güneyi arasındaki mesafe göz önünde bulundurulduğunda mal bolluğunun ve arzının sağlanabilmesi için gelişmiş bir lojistik sisteminin olması gerekmektedir. Bu lojistik ihtiyacı da Çin'de lonca tipi esnaf örgütlenmelerinin ortaya çıkış nedenlerinden biridir.

Çin loncalarının reel fiyatların belirlenmesinde aldıkları rol tıpkı Avrupa'da ve Osmanlı'da olduğu gibi onlara bir tekel rolü kazandırmıştır. XV. ve XVI. yüzyıllarda Çin loncalarının bu tekeli, taşra idaresi tarafından kontrol altında tutuluyor ve gelir dağılımının düzenlenmesinde etkin bir şekilde kullanılıyordu. ${ }^{29}$

Avrupa, Çin ve Osmanlı loncalarının ekonomik hayattaki rolleri incelendiğinde; Avrupa ve Osmanlı'da benzer uygulamalar ve kaidelerle devletin var olan ekonomik hayatın düzenini sağlamanın öncelik kazandığını görüyoruz. Çeşitli sınırlamalar ve kısıtlamalar sayesinde işleyen bir piyasa çerçevesinde düzenlemeler yaptıkları, adil fiyat ve narh gibi sabit fiyat uygulamaları sayesinde uzun dönemde fiyatları ayarlamaya çalıştıkları görülmektedir. XV. ve XVI. yüzyıllarda Çin'de de sabit fiyat uygulamasıyla loncalar tarafından ürün fiyatlarının kontrol edildiğini görüyoruz ancak Çin'de loncaların var olan

25 Hu Ji Chuang, A Concise History Of Chinese Economic Thought (Pekin: Foreign Language Press, 2009), 313.

26 Hu Ji Chuang, 448-90.

27 Christine Moll-Murata, "Chinese Guilds from the Seventeenth to the Twentieth Centuries: An Overview", 219.

28 Peter Golas, "Early Ch'ing Guilds", 573.

29 Earl Thompson ve Charles R. Hickson, Ideology and The Evolution of Vital Institutions: Guilds, The Gold Standart, and Modern International Cooperations (New York: Springer Science, 2001), 171. 
ekonomik düzeni korumaktan ziyade, bölgeler arası ticarette aldıkları etkin rolün daha ön planda olduğu söylenebilir. Aşağıda da detaylı bir şekilde aktarılacağı üzere; Çin'de lonca üyesi olmak için gerekli şartlar Avrupa ve Osmanlı'ya göre çok daha esnektir. Yine Avrupa ve Osmanlı'da lonca sayılarına getirilen kısıtlamaların Çin'de olmaması, Çin'deki kaygıların altında bölgeler arasındaki ticaretin sürekli ve canlı bir şekilde devam etmesine yönelik olduğunu ispatlar niteliktedir.

\subsection{Loncaların Sosyal Hayattaki Yerleri}

Lonca tipi örgütlerin faaliyet gösterdikleri alanlardan bir diğeri de sosyal hayata dair düzenlemelerdir. Gelirin sınıflar arasında "adaletli dağıtımı" görevini üstlenen loncalar toplumdaki sosyal statülerin korunması/iyileştirilmesi için çaba harciyorlardı. Hem oluşmalarındaki mayaya uygun bir şekilde kendi üyelerine yönelik hem de bulundukları topluma fayda sağlamak amaciyla oluşturulmuş kurallara sahiplerdi. Ekonomik hayat ve sosyal hayatın iç içe geçtiği Ortaçağ ekonomilerinde, ekonomik düzeni korumak aslında sosyal düzeni korumayı da beraberinde getiriyordu.

XV. ve XVI. yüzyılda Avrupa'daki loncalar şehirlerin sosyal hayatında önemli bir rol oynuyordu. Loncalar bazen şehirdeki kamusal binaların yapımını, tamirini üstleniyor bazen de şehirdeki yoksulların ihtiyaçlarının giderilmesine katkı sağlıordu. ${ }^{30}$ Şehir hayatıyla iç içe geçmiş lonca kuralları hem lonca içerisinde hem de toplum tarafindan kabul görmekteydi. Örneğin; XV. yüzyılda Londra'daki bir debbağ loncasının kuralları gereği şehre gelen bir yabancının dericilik işinde çalışamayacağı, ancak şehrin özgür insanları arasına kabul edilmiş birinin dericilik faaliyeti gösterebileceği açıkça belirtilmiştir. Ancak, bir kişinin sadece şehrin özgür insanlarından olması lonca örgütlenmesinde üretim yapabileceği anlamına gelmiyordu, kişinin muhakkak o iş kolunda çıraklık süresini doldurmuş, lonca yönetiminin de uygun görmüş olması halinde üretim yapabilirdi. ${ }^{31}$

Loncalar toplumdaki sosyal hayata, kendi kurallarından esinlenerek yön vermeye çalışıyordu. Loncadaki üyeler arası sosyal yardımlaşmanın üst düzey olmasına özen gösteriliyordu. Eğer bir lonca üyesi yaşlandığı için ve artık çalışamadığı için iş alamaz ve muhtaç hale gelirse lonca üyeleri kendi aralarında organize olarak bu kişiye yardım ederdi. Lonca üyesi olan bir kişi yüklü miktarda sipariş almış ve bu işi yetiştiremeyecek haldeyse, yine lonca üyeleri bir araya gelerek bu kişinin elindeki işi bölüşerek ona yardımcı olurlard.$^{32}$ Görüldügüü üzere Avrupa' da loncaların ekonomik hayata dair düzenlemelerinin yanı sıra, sosyal hayatı şekillendiren uygulamaları da mevcuttur.

Avrupa'daki loncaların toplumun sosyal hayatına etkisi ve kendi arasındaki sosyal dayanışmaya benzer bir durum Osmanlı İmparatorluğu'nun klasik döneminde de mevcuttu. Osmanlı' da loncaların ekonomik hayatın yanı sıra sosyal hayata dair düzenlemelerin temeli oluşturulmaya çalışan ahlak anlayışına dayanıyordu. Herhangi bir meslekte faaliyet gösteren

30 S. R. Epstein, "Craft Guilds, Apprenticeship, and Technological Change in Preindustrial Europe", The Journal of Economic History 58, sy 3 (1988): 684-713.

31 Leo Hubermann, Feodal Toplumdan Yirminci Yüzyıla, çev. Murat Belge (istanbul: iletişim Yayınları, 2002), 66-70.

32 Leo Hubermann, 66-70. 
kişinin "insan-1 kâmil”' yani cömert, özverili, disiplinli, dengeli olması gerekiyordu. ${ }^{33}$ Yine meslek erbabı kişiler yetiştirilirken, "eline, beline, diline sahip ol” öğretisi sıklıkla işleniyordu. ${ }^{34}$

Osmanlı loncaları toplumdaki dayanışma ve yardımlaşmaya katkıda bulunarak sosyal hayatta etkinlik gösteriyordu. ${ }^{35}$ Lonca üyesi olan ustaların yaptıkları bağışlar "orta sandığında" toplanırdı. Çıraklık süresini bitirerek kalfalığa geçen veya kalfalıktan ustalığa terfi eden kişiler için orta sandığından bir miktar yardım verilmekteydi. Taşradaki loncalar ise idarecilerle bir araya gelerek "esnaf kesesi" adı altında vakıf benzeri yapılar oluşturarak hem kendi loncaları içinde hem de reayada yardıma muhtaç kişilerin ihtiyaçlarını gidermeye çalışıyordu. ${ }^{36}$

Çin loncalarının sosyal hayatta aldığı roller, Avrupa'daki ve Osmanlı'daki çağdaşlarından geri kalmıyordu. Çin'deki loncaların sosyal hayata dair düzenlemelerinin başında yoksulluğun azaltılması geliyordu. Çin'de loncalara üye olma prensibi "hemşericilik" ilkesine dayanıyordu. Meslek ve iş koluna göre örgütlenen loncalar, hangi bölgede hangi işi yaparsa yapsınlar üyelerinin doğum yerleri aynıydı. Örneğin; XVI. yüzyılda Pekin'de kurulan Kürkçüler Loncasının bütün üyeleri Shantug bölgesinde doğmuşlard. ${ }^{37}$ Yani, doğduğu yerden çok uzaklarda olan yoksul bir kimse, çalışma azmini ve isteğini loncaya ispat edebilirse, lonca ona bir miktar sermaye sağlayarak iş kurmasına yardımcı olurdu. Farklı bir uygulama olarak, doğum yerleri aynı olan yoksul insanlar başka bir loncanın himayesinde örgütlenerek meslek öğreniyor veya ticaret yapıyordu. Bu şekilde hem ülke içindeki ticarete canlılık kazandırılmış oluyor hem de lonca sistemi toplumdaki her bireye firsat eşitliği sağlamış oluyordu. ${ }^{38}$

Çin'deki loncalar halktan ve kendi üyelerinden hastalananlara, yardıma muhtaçlara kendi aralarında para toplayarak yardımcı olmaya çalışırlardı. Yoksulluğun azaltılması ve gelir dağıtımında adaleti sağlama çabalarının yanı sıra, bulundukları bölgede meydana gelebilecek afetlerde hızlı bir şekilde organize olarak halkın yardımına koşmak, halkın ulaşım problemi yaşadığı yerlerdeki yolları onarmak, köprüler yaptırmak gibi kamusal yararı gözeten işleri de loncalar üstlenmişti. ${ }^{39} \mathrm{XV}$. ve XVI. yüzyıllarda Avrupa'da, Osmanlı'da ve Çin'de loncaların; kendi üyelerinin ve toplumun sorunlarına karşı duyarsız kalmadıkları ortak bir özellik olarak karşımıza çıkmaktadır. Ekonominin sosyal alana yansımasında etkin görev alarak, gelir dağılımında adaletin sağlanması ve sosyal yardımlarla ihtiyaç sahibi kişilere ulaşı1ması üç bölgede de benzerlikler göstermektedir. Lonca sisteminin oturduğu

Halil İnalcık, Osmanlı Imparatorluğu Klasik Çağ (1300-1600), 157-58. Halil İnalcık, Devlet-i Aliyye, Osmanlı Imparatorluğu Üzerine Araştırmalar-I, 40-42.

Daha detaylı bilgi için bakınız; Gabriel Baer, "The Administrative, Economic, and Social Functions of Turkish Guilds", International Journal of Middle East Studies 1 (1970): 28-50; Gabriel Baer, "Türk Loncalarının Yapısı Ve Bu Yapının Osmanlı Sosyal Tarihi İçin Önemi, çev.Sami Ferliel”, Ankara Üniversitesi Dil ve TarihCoğrafya Fakültesi Tarih Bölümü Tarih Araştırmaları Dergisi 8, sy 14 (.1963): 99-119.

Osman Nuri Ergin, Mecelle-i Umur-ı Belediye, c. 1 (İstanbul: İstanbul Büyükşehir Belediyesi Kültür İşleri Daire Başkanlığı Yayınları, 1995), 557-70.

Peter Golas, “Early Ch'ing Guilds”, 564.

Zhu Ying, "The Transformation of Traditional Chinese Guilds in Modern Times", Frontiers of History in China 1 (2006): 292-306.

Willim T. Rowe, Hankow: Commerce and Society in a Chinese City, 1796-1889, 60. 
üç sac ayağının sonuncusu ise loncaların taşıdıkları dini misyon ve vurgulardır.

\subsection{Dini Hayat ve Loncalar}

Avrupa'da loncalar dini otorite olan kiliselerle iç içe bir haldeydi. Dini ritüellerin yerine getirilmesinde kiliseyle ortak bir şekilde hareket etmeleri, loncaların kimi zaman dini kardeşlik cemiyetlerine benzetilmelerine yol açmıştır. Lonca üyeleri kiliselerin inşa süreçlerine sadece maddi yardımda bulunmuyor aynı zamanda gönüllü işçilik yaparak katkı vermeye çalışıyorlardı. Kilisenin ve azizlerin şahit gösterildiği kutsal yeminle birbirlerine bağlanan üyeler, ölen üyelerinin törenlerini yapıyor ve kişiyi kendileri gömüyordu. ${ }^{40}$

Loncaların her birinin kendilerini adadıkları ve kurtarıcı olarak gördükleri azizleri vardı. Azizlerin hayatlarında yaşadıkları bir olay, verdikleri ögütler, ilgilendikleri meseleler, yaptıkları meslekler gibi çeşitli etmenlere göre loncalar kendilerine yakın hissettikleri bir azizi kendilerine seçiyorlardı. Örneğin; Londra'da halıcılık işiyle uğraşan esnaf ve zanaatkârlar kendilerine aziz olarak St. Joseph ve St. Luke'u, deriyi işleyerek kemer, kuşak yapan kemerci loncası üyeleri ise St. Lawrence'1 aziz olarak seçmişlerdi. ${ }^{41}$ Loncanın azizlere layık olabilmesi ve azizlerin kendilerini kurtarabilmesi için daha önce incelediğimiz ekonomik ve sosyal alanlarda sıkı bir disiplinle çalışılması gerektiğine inanılırdı. Avrupa'da Geç Ortaçağ veya Erken Modern diyebileceğimiz dönemlerde meslek organizasyonlarının dini ritüellerine oldukça bağlı oldukları söylenebilir.

1498'de Almanya'da Saint Johan Kilisesi'nin kendi tarım arazilerinde kendi buğdayını ve çavdarını yetiştirme imkânı vardı. Ancak kilise ekmeğini bölgedeki firıncılar loncasından temin ettiği için kendi ekmeğini yapamıyordu. Kilise yönetimi tarlaların atıl kalmasını istemediği için, fırıncılar loncasına başvurmuştu. Fırıncılar loncası, Kilisenin bu talebini loncadaki bir fırıncının kiliseye şef olarak ekmek yapımını üstlenmesi ve kilisenin loncaya 16 mark vermesi karşıllı̆ında kabul edilmişti. ${ }^{42}$ Dini kurum ve mesleki organizasyon hem ticari hayatta hem de dini hayatta iç içe geçmiş bir haldeydi. Loncadan birinin kilise için çalışması şeref duyularak yapılan bir işti.

XV. ve XVI. yüzyılda Osmanlı İmparatorluğu'ndaki bazı loncalar ahilik kültürünü koruyarak, İslami değerleri üyeleri arasında yaşatmaya çalışıyordu. ${ }^{43}$ İslam dininin; ticareti, el emeğini, çalışmayı, çalışmak isteyen kişileri desteklemeyi öğütlemesi loncaların da uygulamaya çalıştıkları şeylerdi. Bütün loncalarda olmasa da bazı loncaların dini liderleri olduğu gözlemlenmekteydi. "Şeyh-i Seba" veya "Ahi Baba" adı verilen bu kişilerin esnaf örgütlerinin idaresinde ve ekonomik kararlarında etkisinin az olduğu, sadece manevi bir lider konumunda olduğu söylenebilir. ${ }^{44} \mathrm{Bu}$ manevi liderler, lonca üyeleri arasındaki

40 Steven A. Eipstein, Geç Dönem Ortaçağ Avrupası Ekonomik ve Sosyal Tarih 1000-1500, çev. Serap Işık (İstanbul: İstanbul Bilgi Üniversitesi Yayınları, 2014), 126-35.

41 Gary Richardson, "Craft Guilds And Chrıstıanity In Late-Medieval England A Ratıonal-Choice Analysıs", Rationality and Society Publications, sy 17 (t.y.): 139-89.

42 Leo Hubermann, Feodal Toplumdan Yirminci Yüzyıla, , 71.

43 Eunyeong Yı, 17.Yüzyıl istanbul'unda Lonca Dinamikleri, , 54-58.

44 Mehmet Genç, Osmanlı Imparatorluğunda Devlet ve Ekonomi, 302; Halil İnalıık, Osmanlı Imparatorluğu Klasik Çağ (1300-1600), 159-60. 
anlaşmazlıkları çözmede ve otoriteyle olan ilişkileri düzenlemekte loncalara yardımcı olmaktaydılar. ${ }^{45}$

Avrupa'daki loncaların kendilerine kurtarıcı bir aziz seçtiklerini ve ticaretlerini, hayırlarını, hayatlarını ona adadıklarına yukarıda değinilmişti. Aynı durumun bir benzeri Osmanlı'daki esnaf ve zanaatkârlarında da mevcuttu. Her mesleğin kendine göre bir piri bulunurdu. Tüccarlık yapanların piri Hz.Muhamed (s.a.v), çiftçilerin piri Hz.Adem ( s.a.v), berberlerin piri Selman-1 Farisi, kasapların piri Ebu'l-Muhcin kabul ediliyordu. ${ }^{46} \mathrm{Hem}$ Hristiyanlık inancında hem de İslam inancında mesleklerin kendilerine bir ustaların ustası, pir, üstat belirlemesi ortak bir düşüncenin ürünü gibi görünmektedir.

Çin'deki loncalar uzun yıllar tapınaklarla iç içe faaliyet göstermişlerdir. Lonca üyelerinin üretim ve satış yaptıkları dükkân, depo gibi yerlerin dışında bir de iş konuşmak, bir araya gelmek için tapınaklardan kiraladıkları odaları vardı. XV ve XVI. yüzyıllarda dini hayat ve lonca hayatı o kadar iç içeydi ki; XVII. ve XVIII. Yüzyıllarda inşa edilen lonca binalarının görünüşleri tapınaklarınkinden farksızdı. Lonca kuralları arasında, lonca binaları içinde kutsal ruhları incitecek hareketlerden kaçınılması ve kadınların binaya girerek kutsal ruhları kirletmemesi gerektiği yer alıyordu. Lonca girişlerinde "kutsal ruhlar üretimde ve satışta bizimle olsun" ibaresi asıllıd ${ }^{47}{ }^{47}$

Çin loncalarının tapınaklarda uzun yıllar faaliyet göstermesi, lonca üyelerinin Budist ve Daoist inançlara göre hareket etmelerine neden olmuştu. ${ }^{48}$ Lonca üyeleri dini inançların temsil ettiği erdemli davranışların halk arasında yayılmasında aracı rolü üstlenmişti. Lonca başkanı aynı zamanda kendini iyi ruhlara adayan bir dini lider pozisyondaydı. Loncalar bu inancı "tütsü kabı" metaforuyla ifade ediyordu. Lonca başkanı kâr anlayışından uzak, dayanışmacı, paylaşımcı bir karakter ortaya koyarak tütsü gibi yandığııı, lonca üyeleri ise lonca başkanının yanmasında kendilerini "tütsü kabının ayakları” gibi gördüklerini düşünüyorlardı. Böylece dünyevi hayatın getirdiği maddi kazançları lonca aracılığıyla dağıtarak, ruhlarını arındırdıklarını düşünüyorlardı. ${ }^{49}$ Bir diğer Uzak Doğu ülkesi olan Taiwan'da tüccarlar ve loncalar kendilerini “deniz tanrıçasını" memnun etmeye, Japonya' da ise tıpkı Çin'deki gibi ruhları onurlandırmaya adamışlardı. ${ }^{50}$ Ele alınan üç bölgede ekonomik ve sosyal hayat alanlarındaki lonca faaliyetlerinin benzer yapısının yanı sıra loncaların dini hayata bakış açılarında da oldukça benzer olduğu söylenebilir. Avrupa'da loncaların kendilerini kiliseye adaması ve bir kilise azizini üstat olarak ilan etmesi, Osmanlı'da loncaları dini öğretileri benimseyerek halka örnek olması ve mesleklerin

45 L. C. Wilkins, Forging Urban Solidarities Ottoman Aleppo 1640-1700 (Boston: Brill Academy, 2010), 249-50; Şeyh-i Seba'nın esnaf teşkilatı üzerindeki etkisiyle ilgili daha detaylı olarak bakınız; Mehmet Demiryürek, "Şeyh-i Sebalık Kurumu ve Osmanlı Esnaf Teşkilatı İçindeki Yeri", Türk Kültürü ve Hacı Bektaş Veli Araştırma Dergisi, sy 66 (2013): 17-42.

46 Adnan Gülerman, Ahi Teşkilatının Türk Toplumunun Sosyal ve Ekonomik Yapısı Üzerindeki Etkileri (Ankara: Kültür Bakanlığı Yayınları, 1993), 10.

47 Peter Golas, “Early Ch'ing Guilds”, 577.

48 Karel Davids, Religion, Technology, and the Great and Little Divergencies China and Europe Compared c.700-1800 (Leiden: Brill Academy, 2013), 102-15.

49 Man-houng Lin, “Interpretative Trends in Taiwan's Scholarships on Chinese Business History: 1600 to the Present", Chinese Studies in History, sy 3 (1998): 65-94.

$50 \quad$ Man-houng Lin, 75-96. 
dini bir karakteri pir olarak kabul etmesi, Çin'de ise lonca üyelerinin kendilerini tapınaklara ve kutsal ruhlara adayarak ticaret yapma endişeleri oldukça şaşırtıcı benzerlikler olarak karşımıza çıkmaktadır.

\section{Loncaların Organizasyon Şeması ve Üretim-Denetim Süreci}

Geç Ortaçağ ve erken modern dönemde Avrupa'da loncaların hiyerarşik bir yapıda örgütlendiği görülmektedir. Bu organizasyon içinde çıraklık, kalfalık ve ustalık olmak üzere üç grup bulunmaktaydı. Bu üçlü yapı arasındaki ilişkiler katı kurallarla belirlenmişti. Bir meslek dalında çalışmak isteyen kişiler, lonca tarafından mesleğe kabul edilip çırak olarak işe başlard..$^{51}$ Bir süre çıraklık yapan kişi sınava tabi tutulur ve sınavı geçerse kalfa (garçon, garzoni, valet, compagnon, serviteur) olmaya hak kazanırdı. Çıraklık süresi ülkelere, hatta bölgelere ve mesleklere göre değişiklik gösterebiliyordu. İtalya' da 5 ila 7 yıl arası, Almanya' da 4 yıl, İngiltere'de 7 y1l, Fransa'da 6 ila 8 yıl arası olarak belirlenmişti. ${ }^{52}$

Çırakların ustalarına saygısızlık etmeleri, sözlerinden dışarı çıkmaları gibi durumlar için ayrı ayrı cezalar belirlenmişti. Bir çırak ustasına isyan ederse, Şehir Meclisi önünde ustasından özür dileyene kadar hiçbir usta ona iş vermeyecekti. Yine bir çırağın kendi ustasının dişında başka bir usta yanında çalışmaya başlaması yasaktı. ${ }^{53}$ Organizasyonun devamını sağlamak için bu katı kurallar bütünü gerekli görülüyordu.

Lonca kuralları gereği çıraklar ve kalfalar, ustalarının toplumdaki prestijine zarar verecek durumlardan kaçınmak zorundalardı, yetiştiği ustanın saygınlığını artırmaya çalışmak önemli bir olguydu. Örneğin; Londra'da yeterli sermayeyi temin ederek ve dükkân açma hakkını alarak ustalığa terfi eden bir kalfa, dükkânına ustasının ismini vermek zorundaydı. Yine bazı mesleklerde bu üçlü hiyerarşik yapının takip edilmediği istisnai durumlar olabiliyor, ustalık statüsü babadan oğula geçiyordu. XV. ve XVI. yüzyıllarda Paris'te kasaplık babadan oğula geçiyordu. ${ }^{54}$

Kalfalıktan ustalığa geçiş aşamasında da sistemin katı kurallarının gündelik hayatta yansımalarının bazen esnetildiği gözlenmektedir. Dükkân açmak için yeterli sermayeyi tek başına sağlayamayan birkaç kalfa sermayelerini birleştirerek birinin ustalığ 1 altında dükkân açabilirdi. ${ }^{55} \mathrm{Bu}$ tür ortaklıklarda da doğal olarak kalfa-usta hiyerarşisi olması beklenemezdi.

Loncanın kimler tarafından yönetileceği ve kurumsal olarak nasıl temsil edileceği daha en başta lonca oluşturulurken koyulan kurallar tarafından belirlenmişti. Lonca üyeleri arasında yapılan seçim sonucunda bir ya da iki kişi loncanın en üst makamını temsil etmeye hak kazanıyordu. Bu kişiler loncadaki diğer kişilerle yakınlık gözetmeden ürün denetimini,

\footnotetext{
51 Leo Hubermann, Feodal Toplumdan Yirminci Yüzyıla, 66-70.

52 Alberto Guenzi, Paola Massi, ve Fausto Piola Caselli, Guilds, Markets and Work Regulation in Italy 16th19th Centuries (Roma: Aldershot Press, 1998), 19-31.

53 Leo Hubermann, Feodal Toplumdan Yirminci Yüzyıla, 68; Alberto Guenzi, Paola Massi, ve Fausto Piola Caselli, Guilds, Markets and Work Regulation in italy 16th-19th Centuries, 23.

54 Gervase Rosser, "Crafts, Guilds and the Negotiation of Work in the Medieval Town", Past and Present, sy 154 (1997): 16-17.

55 Gervase Rosser, 18.
} 
hammadde dağılımını eşit bir şekilde yapacaktı. ${ }^{56}$

Lonca içindeki anlaşmazlıklar ve lonca tüzüklerinin ihlalleri gibi durumlarda loncalar davalarına, şehir yönetiminden veya merkezi idareden izin almak şartıyla, kendi lonca mahkemelerinde bakıyorlardı. Bu mahkemelerde lonca mensubu olmayan kişilerin yargılanması da gerçekleşiyordu. Lonca üyeleri arasındaki davalarda çatışma çözülmezse, şehir yönetiminin oluşturduğu kurul veya yetkili yerel mahkemede bu davalar görülüyordu. ${ }^{57}$ $\mathrm{Bu}$ davalar zaman zaman usta-kalfa-çırak arasındaki anlaşmazlıklara da konu olabiliyordu. 1470'de Strasburg'da altın işi yapan ustalar ve kalfalar arasında şiddetli mücadeleler yaşanmış, sonunda şehir yönetimi ayaklanma çıkartan on kalfayı idam ettirmişti. Başka bir örnek davada, terziler loncasının kalfaları mesleki yeterliliklerinin ustalarından daha iyi olduğunu, ancak sermayeleri yetmediği için usta olamadıkların iddia etmişlerdi. ${ }^{58}$

Loncalar şehir ekonomisini canlı tutmak için kendi üretimlerinin önemini, şehir yönetimine kabul ettirebilmişlerdi. Avrupa'da loncaların şehir yönetimleri nezdinde isteklerini kabul ettirebildikleri söylenebilir. Örneğin; lonca kurallarına ve tüzügüne aykırı durumlarda faaliyet gösterdikleri şehrin kolluk kuvvetlerini harekete geçirecek yetkiye sahiplerdi. 1488'te Londra'daki Marangozlar Loncası (The Carpenters of London) şehirde daha ucuza üretim yapan, lonca üyesi olmayan yabancılar tespit ettiğinde, Londra kolluk kuvvetlerinden bu yabancıların yakalanıp, yargılanması için harekete geçmelerini istemişti. ${ }^{59}$ XV. ve XVI. yüzyıllar için Avrupa'daki lonca tipi örgütlenmelerin yapısı genel olarak bu şekildeydi.

Simon Clicquot de Blervache 18.yüzyılın ortalarında “insanların alışveriş yaparken bir malın kalitesinin düşük olduğunu bildikleri halde fiyatı daha ucuz olduğu için tercih edildiğini" gözlemlemiş ve fiyatın insanların günlük alış-verişinde çok önemli bir şey olduğunu gözlemlemişti. ${ }^{60} \mathrm{Bu}$ gözlem daha sonraki yıllarda Ortaçağ ekonomilerindeki katı denetim mekanizmasını anlamakta kullanıldı. Eğer ürün standartları aynı olmazsa, fiyat farklılaşması olabilir ve bu farklılaşma üreticiler arasında rekabete yol açarak mevcut ekonomik sistemin temelini sarsabilirdi. ${ }^{61}$ Daha önce de aktardığımız şekilde loncalar bu fiyat ve kalite denetimini gerçekleştiren mekanizmalardı. Denetim için seçilen kişiler ürünlerin kalitesinin, standartlarının değişmesine müsaade etmez, ürün farklılaştırmasının engellenmesi yoluyla rekabet ortamının doğmasını engellerdi.

Osmanlı İmparatorluğu'nda lonca tipi örgütlenmelerde iki ana grup bulunurdu; hariciler ve dâhililer. Hariciler adı verilen grupta daha önce loncada uzun yıllar mesai harcamış, ancak mevcut durumu çalışmaya el vermeyen emekliler, güçten düşmüşler ve engelli ustalar

56 Georges Renard, Guilds in The Middle Ages, , 36-37.

57 E. Natalie Rothman, Imparatorluk Simsarları, Venedik-istanbul Arası Mekik Dokuyanlar, çev. Ebru Kılıç (İstanbul: Koç Üniversitesi Yayınları, 2016), 95-97.

58 Gervase Rosser, "Crafts, Guilds and the Negotiation of Work in the Medieval Town”, 19.

59 Matthew Davies, "Citizen and “"Foreyns"'; Crafts, Guilds and Regulation in Late Medieval London", içinde Between Regulation and Freedom, Work and Manufactures in European Cities, 14th-18th. Centuries (Cambridge: Cambridge Scholarship Press, 2018), 17.

60 Philippe Minard, “, 'Colbertism Continued? The Inspectorate of Manufacturesand Strategies of Exchange in Eighteenth-Century France',, sayı; 23/3, 2000, s. 492.", French Historical Studies 23, sy 3 (2000): 492.

61 Sheilag Catherine Ogilvie, "The Economics of Guilds", Journal of Economic Perspective, sy 28 (2014): 16992. 
bulunurdu. Bu kişiler loncanın çeşitli yardım sandıklarından aldıkları ücretlerle geçimlerini sağlardı. Diğer grup olan dâhilîlerde ise; yamaklar ve çıraklar, kalfalar, ustalar olmak üzere üçlü bir yapı mevcuttu. ${ }^{62}$ Çocuk yaşta yamaklık yaparak herhangi bir ücret almadan ustanın yanında çalışan yamaklar, daha sonra ustanın onayı olması şartıyla çıraklığa yükseltilirdi. Meslek dalında çıraklıkla başlayan işi öğrenme sürecindeki kişiler, yine mesleki yeterliliğe ustanın onay vermesiyle birlikte kalfalığa yükselirdi. ${ }^{63}$ Uzun yıllar loncada, bir ustanın yanında çalışan kişiler usta olabilmek için hem bağlı bulunduğu loncanın hem de ustasının akdirini kazanmak zorundaydı. Bütün bu süreçler tamamlandıktan sonra ustalığa yükselen kişiye dükkân açma hakkı verilirdi. ${ }^{64}$

Osmanlı Devleti'nde lonca içi hiyerarşinin en üst basamağında kethüdalar bulunurdu. Lonca üyeleri arasından seçilen kethüda hem loncanın en sorumlu kişisi hem de devlet katında temsilci durumundaydı. Kethüda olarak seçilen bir kişi devletten onay/berat almak zorundaydı. Kethüdaların yardımcısı olarak lonca ustası ve yiğitbaşı bulunurdu. Yiğitbaşları lonca içindeki sistemin işlemesini denetler, piyasadan hammadde alarak lonca ustaları arasındaki bölüşümü yapard $1 .{ }^{65}$ Loncadaki ustalar, lonca yönetiminden memnun kalmazlarsa, kethüda ve yiğitbaşını görevinden alabiliyorlardı. ${ }^{66}$

Loncanın belirlediği kuralların bütün üyeler için bağlayıcılığı bulunuyordu. Esnafin ürettiği ürünlerin kaliteleri, sattıkları fiyat ve yer gibi durumlar sürekli olarak denetleniyordu. $\mathrm{Bu}$ denetim mekanizması çift yönlü olarak düşünülebilir. Denetimler hem lonca otoriteleri tarafından hem de devletin görevlendirdiği muhtesip, pazarcıbaşı gibi kişiler tarafından yapılıyordu. Üretim sistemindeki her aşama ve bu aşamalarda görevli kişiler kadı huzurunda kayıt altına alınıyordu. ${ }^{67}$ Üretim ve satış süreçlerinde yaşanan aksilikleri lonca kendi içerisinde çözemezse kadıya taşıyordu. ${ }^{6}{ }^{6}$ İkame mal veya tamamlayıcı ürünleri üreten loncalar hammadde temini veya fiyatın belirlenmesi konusunda kendi aralarında anlaşmaya varamazlarsa yine kadiya başvuruyorlard1 ${ }^{69}$

Hammaddenin dış piyasaya satılmaması ve dışarıdan gelen yabancıların şehirde üretim yapmaması loncaların denetiminde özellikle dikkat edilen konulardı. ${ }^{70}$ Üretim sürecine girecek hammaddenin kime ne kadar verileceği en baştan belirlenir, bunun dışına çıkmak isteyen üreticiler cezalandırılırdı. ${ }^{71}$ Bursa, İstanbul, Selanik gibi pazarlarda ipek

62 Mithat Gürata, Unutulan Adetlerimiz ve Loncalar (Ankara: Tisa Matbaacılık, 1975), 110-11.

63 Mithat Gürata, 112.

64 Eunyeong Yı, 17.Yüzyıl Istanbul'unda Lonca Dinamikleri, 57.

65 Halil İnalcık, Osmanlı Imparatorluğu Klasik Çağ (1300-1600), 159-60.

66 Halil inalcık, 58.

67 Kadı sicillerinde bu kayıt altına alma işlemine “"hüccet vermek”' deniliyordu. Lonca kethüdasının belirlenmesi, yiğitbaşının değişmesi, hammaddeyi nerelerden alıp, nerelere sattığı gibi süreçler kayıt altına alınıyordu. Daha detaylı olarak bakınız Timur Kuran, Mahkeme Kayıtları Işığında 17.Yüzyıl İstanbul'unda Sosyo-Ekonomik Yaşam, c. 1 (İstanbul: Türkiye İş Bankası Kültür Yayınları, 2010), 105,118,145.

68 Timur Kuran, 1:108-16.

69 Ömer Lütfü Barkan, “XV. Asrın Sonunda Bazı Büyük Şehirlerde Eşya ve Yiyecek Fiyatlarının Tesbit ve Teftişi Hususlarını Tanzim Eden Kanunlar", Tarih Vesikaları Dergisi 1, sy 5 (1942): 326.

70 Debbağdan gayrıya ham deri satmayalar. Debbağlar dahi şehirde işleyenlere satub yabana satmayalar. Eslemezlerse haklarından geline aktaran; Osman Nuri Ergin, Mecelle-i Umur-ı Belediye, 1:396.

71 Timur Kuran, Mahkeme Kayıtları Işığında 17.Yüzyıl İstanbul'unda Sosyo-Ekonomik Yaşam, 1:118,162,197. 
dokumacılığıyla uğraşan ve 1.000 Venedik altınını aşan sermayeye sahip ustalar, İran savaşları başlayınca hammadde kıtlığından şikâyet etmiş, loncadan bağımsız hareket etmeye çalışmıştır. Devlet, bu ustaların loncanın dışındaki üretim ve satışa izin vermeyerek, lonca dışındaki örgütlenmeye ve hammadde dağılımına anında müdahale etmiştir. ${ }^{72}$

Çin loncalarının organizasyon şemaları Avrupa'daki ve Osmanlı Devleti'ndeki loncalardan daha farklıdır, hatta kendi içerisinde daha demokratik bir yönetim şekline sahip olduğu söylenebilir. Çin loncalarında düzenleyici ve denetleyici pozisyonunda olan yönetim kuruluna üyeler seçilirdi. Bu üyeler sırayla loncaya başkanlık yapard1. ${ }^{73}$ Örneğin; Shangai Çay Loncası yönetim kuruluna on iki üye seçiyor, bu üyelerden her biri, bir ay süreyle loncaya başkanlık yapıyordu. Halıcılar loncası ise yönetim kurulu diyebileceğimiz beş kişi seçiyor, her birine lonca başkanı görevleri veriyordu. Wenchow'daki Değirmenciler Loncası'nın toplam on altı üyesi bulunuyordu ve aralarından seçtikleri dört kişi loncaya bir yıllığına başkanlık ediyordu. ${ }^{74}$

Loncaya başkanlık eden kişilerin başlıca görevi; üretim için hammaddenin temin edilmesi ve üyeler arasında eşit bir şekilde dağıtılmasıydı. Bunun yanı sıra Çin loncalarının tapınaklarla kurdukları organik ilişki sonucunda lonca başkanlarının tapınaklarının ihtiyaçlarının takip edilmesi ve karşılanması için üyelik aidatlarının toplanılması vardı. Wenchow'daki Eczacılar Loncası'nın yönetimi bir yandan loncayı idare ederken diğer yandan da Şifa Tapınağı'nı da idare ediyordu. ${ }^{75}$. Güney Asya ve Japonya'daki sahil kentlerinde bulunan Çin loncaları zaman zaman diplomatik misyon üstlenerek ikili ilişkileri de yürütüyordu. ${ }^{76}$

Dini kaygilar ve sosyal hayat her ne kadar baskin olsa da loncalar ekonomik temelli kuruluşlardı ve öncelikli hedefleri arasında; ortalama maliyeti düşürmek, ürün fiyatlarını belirlemek ve ürünün kalitesine güven vermek vardı. ${ }^{77}$ Ürün fiyatının belirlenmesinde Avrupa ve Osmanlı' da olduğu gibi doğrudan bir devlet müdahalesi yoktu. Loncalar sattıkları, ürettikleri ürünün fiyatını üyeler arası müzakereler sonucunda belirlerdi. Wenchow'daki Değirmenciler Loncası her aybaşında toplanıp un için bir fiyat belirlerdi. ${ }^{78}$

Piyasadaki ürünlerin denetimi konusunda Çin'in Avrupa ve Osmanlı Devleti'nin gerisindekaldığı söylenebilir. Avrupa'daloncaların rekabetanlayışı veürün farklılaştırmasına gidilmesini istemediği için getirdiği katı kurallar bütünü ve Osmanlı Devleti'nin devlet kurumlarıyla ve kurallarıyla denetlediği piyasa anlayışı Çin'de daha esnektir. Ürünlerin denetimi ve standartları loncanın kendisine bırakılmıştır. Loncaların resmi kurumlarla iş birliği yapmadığı ve piyasa adına karar alma yetkisi olmadığı için Çin'de genel bir ürün denetim mekanizması bulunmamaktadır. Bunun yerine her bir loncanın kendi içinde

72 Şevket Pamuk, Osmanlı-Türkiye Iktisadi Tarihi 1500-1914, 55-65.

73 Hosea Ballou Morse, The Gilds of China: With an Account of the Gild Merchant or Co-Hong of Canton (Londra: Longmans\&Green and Co., 1909), 12.

74 Hosea Ballou Morse, 12.

75 Hosea Ballou Morse, 14.

76 Peter Golas, “Early Ch'ing Guilds”, 221.

77 Avner Greif ve Guido Tabellini, "The clan and the corporation: Sustaining cooperation in China and Europe", Journal of Comparative Economics, sy 45 (2017): 1-35.

Hosea Ballou Morse, The Gilds of China: With an Account of the Gild Merchant or Co-Hong of Canton, 13. 
koyduğu kurallar bulunmaktadır. Bu durum da; Çin'de her bir ürün için, her bir loncada farklı kurallar koyulması anlamına gelmektedir. ${ }^{79}$

\section{Loncalar ve Devlet Otoritesi}

Avrupa'da loncalar kent hayatı ile iç içe geçmiş kurumlardı. Kent yararına iş yapan ve kentle ortak hareket eden yapılardı. Şehir surları içindeki ekonominin canlı ve kârlı olduğu durumlarda loncalar, otorite tarafindan destekleniyordu. Ancak, ticari faaliyetler surların dışına, taşraya yayılmaya başlayınca loncalar; hem pazarlama faaliyetleri açısından hem de ürün denetimi yapma hususunda yetersiz kalıyorlard1. ${ }^{80}$

Şehir merkezlerinin ve taşranın iktisadi olarak birleşme sürecinde, loncaların iktisadi, siyasi ve dini rolleri azalmaya başlamıştı. Lonca kurumu yerine artık kendi içerisinde başka bir kültürü olan ve farklı değerleri temsil eden diğer bir kurum, tüccar birlikleri öne çıkmaya başlamışt. ${ }^{81} \mathrm{Bu}$ süreçte lonca sistemine üye olmak kişiler için cazibesini kaybetmeye başlamıştır.

Loncaya üye olmak her şeyden önce "gönüllülük" esasına dayanmaktaydı. Loncaya üye olan kişinin üretim sürecinde sarf ettiği efor azalıyordu, bir başka deyişle örtük maliyetlerini düşürüyordu. Lonca üyesi olan bir kişi, hammadde alımı, dağıtımı planlamasını yapmak zorunda kalmıyor yine tüketiciyle ilişkilerini lonca çatısı altında daha rahat sürdürüyordu. ${ }^{82}$ Avrupa'da XV. ve XVI. yüzyıllarda kişilerin lonca üyesi olması yapabilecekleri en kârlı hareketti.$^{83}$ Ancak, tüccarların devreye girmesiyle beraber yeni oluşan ticari sistemde loncaların şehir surları dışında işlevsiz kaldı. Loncalar, devletin ya da şehir idaresinin desteği olmadan varlıklarını sürdüremezlerdi. Yeni ticari düzen ve teknolojik gelişmelerle birlikte kapitalizm ve endüstrileşme serüveninde lonca dinamikleri yetersiz kalmaktaydı. Rekabetçi yapıdan yoksun lonca düzeninin Avrupa'da sonuna geliniyordu. ${ }^{84}$ Loncalara verilen destek tüccarlara aktarılmaya başlandı. Ekonomik

79 Hosea Ballou Morse, The Trade and Administration of the Chinese Empire (Londra: Longmans\&Green and Co., 1908), 170.

80 Lewis Mumford, Tarih Boyunca Kent, Kökenleri Geçirdiği Dönüşümler ve Geleceği, çev. Gürol Koca ve Tamer Tosun (İstanbul: Ayrıntı Yayınları, 2007), 419-28.

81 Avrupa'da tüccarların gelişimi ve öne çıkma süreciyle ilgili detaylı çalışmalar için bakınız Merry E.WiesnerHanks, Erken Modern Dönemde Avrupa, çev. Hamit Çalışkan, (İstanbul: Türkiye İş Bankası Kültür Yayınları, 2009); Nathan Rosenberg ve L.E. Birdzell, Batı Nasıl Zengin Oldu.

82 Gary Richardson, "A Tale of Two Theories: Monopolies and Craft Guilds in Medieaval England and Modern Imagination", Journal of the History of Economic Thaught 2, sy 23 (2001): 236.

83 Der-Yuan-Yang, "The Evolution of Craftsmen Guilds: A Coordination Perspective" (42. Annual Meeting of the CEA, Vancover: University of British Columbia), Bu konuyla ilgili yapılan birkaç matematiksel çalışma da kişilerin loncaya üye olmalarının mevcut şartlarda en "'optimal"' hareket olduğu tezini desteklemektedir. Lagunoff ve Matsui'nin oyuncuların sabırlı oldukları takdirde Pareto Optimum noktasına ulaşacağı varsayımlarının loncalara uyarlanması sonucu; bir kişinin loncaya üye olmasını en mantıklı, kazançlı hareket olduğu tespit edilmiştir. Bununla ilgili detaylı olarak bakınız, erişim 21 Mayıs 2020, https://www. researchgate.net/publication/228419746_The_Evolution_of_Craftsmen_Guilds_A_Coordination_ Perspective; Yine, aile veya klan tipi ilişkilerin piyasaya etkisine $\bar{k}$ ıyasla loncāaki çırak-usta tipi üretim tarzının piyasaya daha çok etkisi olduğu, lonca üyeliğinin daha kazançlı olduğunun tespit edildiği bir çalışma için bakınız David De La Croix, Mathias Doepke, ve Joel Mokyr, "Clans, Guilds, and Markets: Apprenticeship Institutions and Growth in Pre-industrial Economy", The Quarterly Journal of Economics 1, sy 133 (2018): 1-70.

84 Pauline Gregg, Social and Economic History of Britain 1766-1970, 6. bs (Londra: George\&Harrap Co.Ltd., 1971), 66-67. 
hayattaki bu dönüşüm süreci XVIII. yüzyıla kadar devam etti. ${ }^{85}$ XVIII. yüzyıla gelindiğinde Avrupa'da lonca sayılarında hızlı bir düşüş yaşanmış, lonca mensubu bireyler de yeni sisteme ayak uydurmaya çalışır hale gelmişti. ${ }^{86}$

Osmanlı İmparatorluğu'nda loncaların etkilerini kaybetme serüveni tıpkı Avrupa'daki gibi XVII. Yüzyılda başlamıştı, fakat bu güç kaybının sebepleri daha farklıydı. Osmanlı İmparatorluğu'nun klasik dönemindeki iktisadi prensipler gereği lonca ve otorite ilişkileri iç içe geçmiş durumdayd. Loncalar ve devlet arasındaki pratikler iki tarafa da güven sağlıyordu. Loncalar, varlıklarını sürdürebilmek için ve tekel güçlerini devam ettirebilmek için devlete ihtiyaç duyuyorlard1 ${ }^{87}$ Devlet ise kendi kendini denetleyen, rekabeti azaltarak piyasa fiyatlarında dalgalanmaya izin vermeyen ve kendi koyduğu kurallar dışına çıkmayan bu kuruma destek veriyordu. Ancak bu katı kurallar sistemi, dış gelişmelere ani reaksiyon vermede ve yapılan hatalardan geri dönülmesine müsaade eden esnek bir sistem değildi. XVII. Yüzyıldan itibaren Osmanlı loncalarının üyeleri yabancı tüccarlar karşısında ezilmeye başladığında da esnek davranamamışlardı. ${ }^{88}$

Ticari rekabetin azalması ve Osmanlı Devleti'nin uzun ve yıpratıcı savaşlarla birlikte ekonomik alanda sıkıntılar yaşaması, devleti sürekli olarak bir kaynak arayışına sevk etmişti. XVI. yüzyılın sonunda yapılan büyük tağşiş, tımar sisteminin bozulmaya başlaması ve loncaları en çok etkileyen uygulamalardan biri iltizam usulünün yaygınlaşması gibi arayışlar devletin klasik iktisadi sistemindeki bozulmaları işaret etmektedir.

XV. ve XVI. yüzy1lda loncalardan sorumlu olan kethüdalar; lonca için çalışan, piyasa fiyatlarını düzenlemek için yardımcı olan, devletin tayin ettiği görevlilerle lonca arasındaki ilişkileri sağlayan görevlilerdi. Ancak iltizam usulünün yaygınlaşmasıyla beraber, lonca kethüdalığ 1 gibi mevkiler satışa çıkarılmaya başland $1{ }^{89} \mathrm{Bu}$ mevkilerin para karşıllğı satılması yukarıda değinilen lonca geleneklerine ve işleyiş biçimine karşı bir durumdu. Rekabet ve tekel gücünü kaybetmeye başlayan, ayrıca içeriden de bozulmaya başlayan lonca sistemi zamanla önemini büyük ölçüde kaybedecekti. Loncaların piyasada önemini kaybetmesi Osmanlı iktisadi düzenindeki narh gibi çok önemli kurumların da işlememesine sebep olacaktı. Bu durum dönemin hiciv şairlerinden Osmanzâde Ta'ib'in "Kaside-i Arizatu'l Fukara"' adlı kasidesine konu olmuş ve şair:

85 Hugo Soly, "The Political Economy of European Craft Guilds; Power Relations and Economic Strategies of Merchants and Master Artisans in the Medieval and Early Modern Textile Industries", IRSH, sy 53 (2008): 45-71.

86 Lonca ustalarının sisteme eklenmesi ve proto-endüstri çağında tüccar, işveren olarak dönüşmesi, kalfa ve çıraklık yapan kişilerin ücretli çalışan haline gelmesi literatürde “"Verlagssystem"' olarak adlandırılmaktadır. Konuyla ilgili olarak detaylı olarak bakınız Fernand Braudel, Civilization\&Capitalism 15th-18th Century Vol:Il The Wheels of Commerce (Los Angeles: University of California Press, 1992); Hermann Kellenbenz, The Rise of the European Economy: An Economic History of Continental Europe from the Fifteenth to the Eighteenth Century (New York: Holmes\&Meier Publish, 1976); Douglass C.North ve Robert Paul Thomas, The Rises of the Western World A New Economic History (New York: Cambridge University Press, 1973).

87 Konuyla ilgili detaylı olarak bakınız; Mehmet Genç, Osmanlı imparatorluğunda Devlet ve Ekonomi.

88 Robert Mantran, 16.ve 17. Yüzyılda Istanbul'da Gündelik Hayat, çev. Mehmet Ali Kılıçbay (İstanbul: Eren Yayınları, 1991), 99-100.

89 Suraiya Faroqhi, "Lonca ve Zanaat Temelli Mevkileri Satın Alma: Bir Ön İnceleme”, içinde İlhan Tekeli Için Armağan Yazılar (İstanbul: Tarih Vakfı Yurt Yayınları, 2004), 219-35. 
" Simsıkı narh'1 koy ki sultanım

Defola şehrin halkından bu gala",

"Yakalat nerede muhtekir var ise

Vezirlik şanını eyle i'fa" ${ }_{90}$

şeklinde düşüncelerini dile getirmiştir. Hayat pahalılı̆̆ından ve yoksulluktan şikâyet eden şair, bu durumun ancak sultanın katı tedbirler alarak çözebileceğini, çözümün de narh sisteminin sıkı bir şekilde uygulanması olduğunu belirtmiştir.

XV. ve XVI. yüzyılda Çin loncalarının sayılarına baktığımız zaman, Avrupa ve Osmanlı'nın bir hayli gerisinde olduğu görülmektedir. Ancak, Avrupa'da ve Osmanlı'da loncaların nitelik ve nicelik olarak düşüşe geçtiği dönemlerde, Çin'in kum saati tersine dönmüş ve lonca sayılarında çarpıcı bir artış yaşanmıştır. $\mathrm{Bu}$ artışın temel nedeni ise Çin'in batıyla olan ilişkilerinin artması ve batı piyasalarına eklemlenmesi olarak açıklanmıştır. ${ }^{91}$ Burada, peki Osmanlı İmparatorluğu'nda batıyla olan ilişkilerin artmaya başladığ 1 yüzyıllarda Osmanlı İmparatorluğu'nda loncaların sayısı neden artmamıştır? Neden loncalar önemini kaybetmeye başlamıştır gibi sorular akla gelmektedir. Osmanlı İmparatorluğu'ndaki üretim tarzının ve Batı'nın endüstriyel üretim tarzının farklılaşması, Osmanlı coğrafyasının Batı üretimini destekleyen bir hammadde pazarı haline gelmesi, mamul malların rekabetinin zayıf kalması nedeniyle üretim yerine ticarete yoğunlaşılması lonca tipi örgütlerin önemini kaybetmesine neden olmuştur denilebilir. Ayrıca Osmanlı İmparatorluğu'nun klasik kurumlarının hemen hemen hepsinin bozulmaya başladığ 1 bir dönemde, loncaların niteliğinin bozulması ülke içindeki ekonomik-sosyal ve kültürel nedenlerle de ilişkili olduğu açıktır.

Çin'de otorite ve loncalar arasındaki ilişki diğer çağdaşlarına göre daha esnek durumdaydı. Otorite, loncalarla doğrudan ilişki kurmak yerine yerel idareciler vasıtasıyla loncaları yönetiyordu. Devletin temel rolü, loncaların üretim ve satış yapabilmeleri için gerekli olan şartları sağlamak ve var olan şartları iyileştirmekti. ${ }^{92}$ Ancak, şartlar ne kadar iyileştirilirse iyileştirilsin lonca tipi örgütlenmede üretim el emeğine dayanıyordu. Batı dünyasının endüstrileşme sürecinde geleneksel üretim yöntemleri terk ediliyordu. $\mathrm{Bu}$ durum Çin loncalarının, Endüstri Devrimi'nin gecikmesinin en önemli sorunlarından biri olarak görülmesine sebep oluyordu. Loncaların oluşturdukları tekeller üretimin bölgesel ölçekte kalmasına neden oluyor, uluslararası ticari faaliyetlerin ülke içine girmesine izin verilmiyordu.

Çin'in batıyla olan ilişkilerinin gelişmeye başladığg süreçte loncalar öncü rol oynamıştır. Çin loncalarının otoriteyle kurduğu ilişkilerin yapısının esnek olması sayesinde uluslararası ticarete rahatça uyum sağlayabilmişlerdir. Osmanlı İmparatorluğu'ndaki loncaların katı nitelikte olması Osmanlı loncalarının sonunu getirirken, Çin'deki loncaların

90 Ahmet Kabaklı, Şiir Incelemeleri, 2. bs (istanbul: Türk Edebiyat Vakfı Yayınları, 2003), 150.

91 Robert Allen vd., "Wages, Prices and Living Standarts in China 1739-1925 in Comparision with Europe, Japan and India", Economic History Review, sy 64 (2011): 8-38.

92 Jan Lucassen, Luiten von Zanden, ve Tine de Moor, "The Return of the Guilds: Towards a Global History of the Guilds in Pre-Industrial Times", IRSH, 2008, 5-18. 
esnek yapısı üretim metodunu da değiştirmiştir. XV. ve XVI. yüzyıla kıyasla da loncaların sayısında artışlar meydan gelmiştir..$^{93}$

\section{Sonuç}

Esnaf tipi örgütlenmelerin ortaya çıkışları ile ilgili tezler ele alınan üç bölgede de “bilinmeyene karşı" veya zor koşullarla birlikte mücadele etmek için "dayanışma" duygusuna, ya da ilahi bir güç etrafında şekillenen ve dini motiflerle bezenmiş topluluklar oldukları varsayımına dayanmaktadır. Bu köken meselesi tam olarak çözülememiş, yeni kayıtlar bulundukça literatürde tartışmalar devam etmektedir.

Loncaların içinde bulundukları toplumda bazı roller almaktadırlar. Bunlar makalede ekonomik, sosyal ve dini alan olmak üzere üç başlıkta incelenmiştir. Ekonomik alanda loncaların oynadığı rol iktisadi düşüncenin pratiğe dönüşmesini sağlamıştır. Fiyatların kontrol altında tutulması, bölgeler arası ticaretin zenginleşmesi, iş bölümü- organizasyonun devlet tarafından yapılmasına gerek duyulmaması, haksız kazancın önüne geçilmesi, tüketici güvenliğinin sağlanması, halkın ihtiyaç duyduğu maddelerin üretim-tedarik sürecinde bir aksaklık yaşanmaması gibi konularda loncalar çok kilit kurumlardı. Sosyal hayatta, devletin yükünü azaltan, üreticilerin kendi aralarındaki yardımlaşmalarını destekleyen kuruluşlardı. Loncaların kendilerine bir kutsallık atfettikleri ve kendi dini görüşleri etrafında hareket etmeleri loncaları dini alanda da etkin kurumlar haline getirmiştir.

Ekonomik, sosyal ve dini alanda bu derece etkin olan kurumların kendi içlerinde bir takım kuralları ve/veya kanunları vardı. Loncaya üye olduktan sonra çıraklık, kalfalık ve ustalık şeklinde giden bir hiyerarşi mevcuttur. Üç coğrafyada da bu hiyerarşi ortak bir özelliktir ancak hiyerarşik düzende ilerlemek için geçirilen süreler farkl1lık gösterebilmektedir.

Devlet gelenekleri ve yönetim şekilleri çok farklı koşullara bağlı olduğu için bahsi geçen üç coğrafi bölgede loncalarla kurulan ilişki biçimleri de farklıdır. Avrupa' da devletlerin loncaları özerk bir kurum olarak kabul etmeleri loncalara aktif hareket sahası sağlamıştır ve güçlü lonca yapılarının ortaya çıkmasına yol açmıştır. Osmanlı İmparatorluğu'nda devletin loncaları kendisiyle ortak hareket etmek zorunda olan kurumlar olarak görmesi, genellikle loncaların "devletin otoritesi altında" işleyen kurumlar olarak algılanmasına neden olmuştur. Çin'de ise loncalar ve devlet arasında ciddi gerilimler meydana gelmemekle beraber, bölgesel ticarette hayati bir rol oynadığı için, Çin loncalarının ortaçağda Avrupa ve Osmanlı'ya göre esnek olduğu söylenebilir.

93 Harold M. Vinackle, "Obstacles to Industrial Development in China”, The Annals of American Academy of Political and Social Science, sy 152 (1930): 173-80. 


\section{KAYNAKÇA}

Adnan Gülerman. Ahi Teşkilatının Türk Toplumunun Sosyal ve Ekonomik Yapısı Üzerindeki Etkileri. Ankara: Kültür Bakanlığı Yayınları, 1993.

Ahmet Kabaklı. Şiir İncelemeleri. 2. bs. İstanbul: Türk Edebiyat Vakfı Yayınları, 2003.

Alberto Guenzi, Paola Massi, ve Fausto Piola Caselli. Guilds, Markets and Work Regulation in İtaly 16th-19th Centuries. Roma: Aldershot Press, 1998.

Avner Greif, ve Guido Tabellini. "The clan and the corporation: Sustaining cooperation in China and Europe". Journal of Comparative Economics, sy 45 (2017): 1-35.

Bernard Lewis. "The Islamic Guilds". The Economic History Review 8, sy 1 (1937): 20-37.

Christine Moll-Murata. "Chinese Guilds from the Seventeenth to the Twentieth Centuries: An Overview”. IRSH 53, sy 1 (2008): 213-45.

David De La Croix, Mathias Doepke, ve Joel Mokyr. "Clans, Guilds, and Markets: Apprenticeship Institutions and Growth in Pre-industrial Economy". The Quarterly Journal of Economics 1, sy 133 (2018): 1-70.

Der-Yuan-Yang. "The Evolution of Craftsmen Guilds: A Coordination Perspective". Vancover: University of British Columbia. Erişim 21 Mayis 2020. https://www.researchgate. net/publication/228419746_The_Evolution_of_Craftsmen_Guilds_A_Coordination_ Perspective.

Douglass C.North, ve Robert Paul Thomas. The Rises of the Western World A New Economic Hsitory. New York: Cambridge University Press, 1973.

E. Natalie Rothman. İmparatorluk Simsarları, Venedik-İstanbul Aras1 Mekik Dokuyanlar, çev. Ebru Kılıç. İstanbul: Koç Üniversitesi Yayınları, 2016.

Earl Thompson, ve Charles R. Hickson. Ideology and The Evolution of Vital Institutions: Guilds, The Gold Standart, and Modern International Cooperations. New York: Springer Science, 2001.

Eunyeong Y1. 17.Yüzy1 İstanbul'unda Lonca Dinamikleri, çev. Barış Zeren. İstanbul: Türkiye İş Bankası Kültür Yayınları, 2018.

Fernand Braudel. Civilization\&Capitalism 15th-18th Century Vol:II The Wheels of Commerce. Los Angeles: University of California Press, 1992.

Gabriel Baer. Fellah and Townsmen in the Middle East: Studies in Social History. Londra: Frank Cass, 1982.

—. "The Administrative, Economic, and Social Functions of Turkish Guilds". International Journal of Middle East Studies 1 (1970): 28-50.

. "Türk Loncalarının Yapısı Ve Bu Yapının Osmanlı Sosyal Tarihi İçin Önemi, çev.Sami Ferliel”. Ankara Üniversitesi Dil ve Tarih-Coğrafya Fakültesi Tarih Bölümü Tarih Araştırmaları Dergisi 8, sy 14 (1963): 99-119. 
Gary Richardson. "A Tale of Two Theories: Monopolies and Craft Guilds in Medieaval England and Modern Imagination". Journal of the History of Economic Thaught 2, sy 23 (2001): 217-42.

. "Craft Guilds And Chrıstıanity In Late-Medieval England A Ratıonal-Choice Analysis". Rationality and Society Publications, sy 17 (t.y.): 139-89.

Georges Renard. Guilds in The Middle Ages, çev. Dorothy Terry. Ontario: Batoche Books, 2000.

Gervase Rosser. "Crafts, Guilds and the Negotiation of Work in the Medieval Town". Past and Present, sy 154 (1997): 3-31.

Halil İnalcık. Devlet-i Aliyye, Osmanlı İmparatorluğu Üzerine Araştırmalar-I. 52. bs. İstanbul: Türkiye İş Bankası Kültür Yayınları, 2013.

—. Osmanlı İmparatorluğu Klasik Çağ (1300-1600), çev. Ruşen Sezer. 18. bs. İstanbul: Yapı Kredi Yayınları, 2013.

Harold M. Vinackle. "Obstacles to Industrial Development in China". The Annals of American Academy of Political and Social Science, sy 152 (1930): 173-80.

Henri Pirenne. Ortaçağ Avrupa'sının Ekonomik ve Sosyal Tarihi, çev. Uygar Kocabaşoğlu. 3. bs. İstanbul: İletişim Yayınları, 2011.

Hermann Kellenbenz. The Rise of the European Economy: An Economic History of Continental Europe from the Fifteenth to the Eighteenth Century. New York: Holmes\&Meier Publish, 1976.

Hosea Ballou Morse. The Gilds of China: With an Account of the Gild Merchant or Co-Hong of Canton. Londra: Longmans\&Green and Co., 1909.

- The Trade and Administration of the Chinese Empire. Londra: Longmans\&Green and Co., 1908.

Hu Ji Chuang. A Concise History Of Chinese Economic Thought. Pekin: Foreign Language Press, 2009.

Hugo Soly. "The Political Economy of European Craft Guilds; Power Relations and Economic Strategies of Merchants and Master Artisans in the Medieval and Early Modern Textile Industries”. IRSH, sy 53 (2008): 45-71.

Jacques Le Goff. Ortaçağ Batı Uygarlığı, çev. Hanife Güven, Uğur Güven. 280280. Ankara: DoğuBatı Yayınları, 2015.

Jan Lucassen, Luiten von Zanden, ve Tine de Moor. "The Return of the Guilds: Towards a Global History of the Guilds in Pre-Industrial Times". IRSH, 2008, 5-18.

John Baldwin. Masters,Princes, and Merchants, The Social Views of Peter The Chanter His Circle. C. 1. 2 c. Princeton: Princeton University Press, 1970.

. "The Medieval Theories of Just Price; Romanists, Canonists, and Theologians in Twelfth and Thirteenth Centuries". Transactions of The America Philosophical Society 49, sy 4 (1959): 1-92. 
Karel Davids. Religion, Technology, and the Great and Little Divergencies China and Europe Compared c.700-1800. Leiden: Brill Academy, 2013.

L. C. Wilkins. Forging Urban Solidarities Ottoman Aleppo 1640-1700. Boston: Brill Academy, 2010.

Leo Hubermann. Feodal Toplumdan Yirminci Yüzyıla, çev. Murat Belge. İstanbul: İletişim Yayınları, 2002.

Lewis Mumford. Tarih Boyunca Kent, Kökenleri Geçirdiği Dönüşümler ve Geleceği, çev. Gürol Koca ve Tamer Tosun. İstanbul: Ayrıntı Yayınları, 2007.

Man-houng Lin. “Interpretative Trends in Taiwan's Scholarships on Chinese Business History: 1600 to the Present". Chinese Studies in History, sy 3 (1998): 65-94.

Matthew Davies. "Citizen and "Foreyns"; Crafts, Guilds and Regulation in Late Medieval London". Içinde Between Regulation and Freedom, Work and Manufactures in European Cities, 14th-18th. Centuries. Cambridge: Cambridge Scholarship Press, 2018.

Mehmet Ali Ağaoğulları. Sokratesen Jakobenlere Batı'da Siyasal Düşünce. 2. bs. İstanbul: İletişim Yayınları, 2011.

Mehmet Demiryürek. "Şeyh-i Sebalık Kurumu ve Osmanlı Esnaf Teşkilatı İçindeki Yeri”. Türk Kültürü ve Hacı Bektaş Veli Araştırma Dergisi, sy 66 (2013): 17-42.

Mehmet Genç. Osmanlı İmparatorluğunda Devlet ve Ekonomi. 9. bs. İstanbul: Ötüken Yayınları, 2013.

Merry E.Wiesner-Hanks. Erken Modern Dönemde Avrupa, çev. Hamit Çalışkan,. İstanbul: Türkiye İş Bankası Kültür Yayınları, 2009.

Mithat Gürata. Unutulan Adetlerimiz ve Loncalar. Ankara: Tisa Matbaacılık, 1975.

Murat Özyüksel. Feodalite ve Osmanlı Toplumu, Derin Yayınları, İstanbul. İstanbul: Derin Yayınları, 2007.

Mübahat Kütükoğlu. "Narh”. Içinde TDV İslam Ansiklopedisi, 32:390-91. Ankara: Türkiye Diyanet vakfi, 2006.

Nathan Rosenberg, ve L.E. Birdzell. Batı Nasıl Zengin Oldu, çev, Erdal Güven. İstanbul: Form Yayınlar1, 1992.

Osman Nuri Ergin. Mecelle-i Umur-1 Belediye. C. 1. İstanbul: İstanbul Büyükşehir Belediyesi Kültür İşleri Daire Başkanlığı Yayınları, 1995.

Ömer Lütfü Barkan. "XV.Asrın Sonunda Bazı Büyük Şehirlerde Eşya ve Yiyecek Fiyatlarının Tesbit ve Teftişi Hususlarını Tanzim Eden Kanunlar”. Tarih Vesikaları Dergisi 1, sy 5 (1942): 326-40.

Pauline Gregg. Social and Economic History of Britain 1766-1970. 6. bs. Londra: George\&Harrap Co.Ltd., 1971.

Peter Golas. "Early Ch'ing Guilds". Içinde The City in Late Imperial China. Stanford: Stanford Universtiy Press, 1977. 
Philippe Minard. “, 'Colbertism Continued? The Inspectorate of Manufacturesand Strategies of Exchange in Eighteenth-Century France',, say1; 23/3, 2000, s. 492." French Historical Studies 23, sy 3 (2000): 477-96.

Raymond de Roover. "The Concept of the Just Price: Theory and Economic Policy". The Journal of Economic History 18, sy 4 (1958): 418-34.

Robert Allen, Jean Pascal Bassino, Debin Ma, Christine Moll-Murata, ve Luiten von Zanden. "Wages, Prices and Living Standarts in China 1739-1925 in Comparision with Europe, Japan and India". Economic History Review, sy 64 (2011): 8-38.

Robert Mantran. 16.ve 17. Yüzyılda İstanbul'da Gündelik Hayat, .çev. Mehmet Ali Kılıçbay. İstanbul: Eren Yayınları, 1991.

S. R. Epstein. "Craft Guilds, Apprenticeship, and Technological Change in Preindustrial Europe". The Journal of Economic History 58, sy 3 (1988): 684-713.

Sheilag Catherine Ogilvie. "The Economics of Guilds". Journal of Economic Perspective, sy 28 (2014): 169-92.

Steven A. Eipstein. Geç Dönem Ortaçağ Avrupası Ekonomik ve Sosyal Tarih 10001500, çev. Serap Işı.k. İstanbul: İstanbul Bilgi Üniversitesi Yayınları, 2014.

Suraiya Faroqh. Osmanlı Kültürü ve Gündelik Yaşam, çev. Elif Kılıç. 5. bs. İstanbul: Tarih Vakfi Yurt Yayınları, 2005.

Suraiya Faroqhi. "Lonca ve Zanaat Temelli Mevkileri Satın Alma: Bir Ön İnceleme”. Içinde İlhan Tekeli İçin Armağan Yazılar, 219-35. İstanbul: Tarih Vakfı Yurt Yayınları, 2004.

Şevket Pamuk. Osmanl1-Türkiye İktisadi Tarihi 1500-1914. 9. bs. İstanbul: İletişim Yayınları, 2014.

Timur Kuran. Mahkeme Kayıtları Işı̆̆ında 17.Yüzyıl İstanbul'unda Sosyo-Ekonomik Yaşam. C. 1. İstanbul: Türkiye İş Bankası Kültür Yayınları, 2010.

Umberto Eco. Ortaçağ, Barbarlar-Hristiyanlar- Müslümanlar çev. Leyla Tonguç Basmac1. 2. bs. İstanbul: Alfa Yayınları, 2014.

Willim T. Rowe. Hankow: Commerce and Society in a Chinese City, 1796-1889. Stanford: CA, 1984.

Zhu Ying. "The Transformation of Traditional Chinese Guilds in Modern Times". Frontiers of History in China 1 (2006): 292-306. 